\title{
The Role of Production Costs in the Management of Poultry Sector of the Region
}

\author{
Safiullina A. M. ${ }^{1}$, Davydova I. Sh. ${ }^{1}$, Klimanova A. R. ${ }^{1}$ \& Ganeeva D. A. ${ }^{2}$ \\ ${ }^{1}$ Institute of Economics, Management and Law, Kazan, Russian Federation \\ ${ }^{2}$ Kazan Federal University, Institute of Management, Economics and Finance, Kazan, Russia \\ Correspondence: Safiullina A. M., Institute of Economics, Management and Law, Kazan, Russian Federation.
}

Received: March 19, 2015 Accepted: March 31, 2015 Online Published: April 30, 2015

doi:10.5539/ass.v11n11p406 URL: http://dx.doi.org/10.5539/ass.v11n11p406

\begin{abstract}
The article analyzes the economic characteristics of poultry sector development on the example of large poultry farms in Tatarstan Republic. Special attention is paid to the role of production costs in poultry sector in increasing the efficiency of production-financial functioning of economic subjects. The authors prove that to compare the costs dynamics, the relative indicators should be cast to each 100 sq.m. of a farm, i.e. the conditions should be typified in order to analyze the structure, trends and development prospects of the farms' production-financial functioning. Conclusions are formulated, that the efficient management of production-financial functioning costs and structure will allow to achieve the increased efficiency of production-financial functioning of poultry farms. The crucial significance is attributed to innovative management, budget financing, special programs financing, and various forms of state-private partnership, which would increase the investment attraction of poultry sector.
\end{abstract}

Keywords: poultry sector, production costs, Tatarstan Republic, production-financial functioning, innovative management

\section{Introduction}

Food production is one of the topical issues of today. "Food production is the first condition of life", wrote Karl Marx (Marks \& Engels). This process must be unrepeated, as the humanity cannot stop consuming but has to increase the food production due to the increase of consumption and population. The efficient cost management is a prerequisite to increase the production intensity and welfare (Barrett, 2010; Tscharntke et al., 2012).

Analyzing and estimating the financial condition of a farm, special attention should be paid to the level of its cost management (Dobrynin, 2001). It has been stated that the efficiency of cost management is the necessary condition of increasing the efficiency of production-financial functioning of economic subjects, in particular, poultry farms (Dzh, 2012).

\section{Literature Review}

The theory of agricultural production efficiency, the methodological approaches to its reserves estimation are profoundly studied in the works by A. I. Altukhov, M. A. Ananyev, V. R. Boyev, I. N. Buzdalov, V. A. Dobrynin, V. P. Zakharov, V. I. Klukach, E. G. Kovalenko, A. I. Kostyaev, G. G. Kotov, E. G. Lysenko, G. I. Makin, A. A. Maremukov, A. A. Nikonov, Z. F. Pulatov, L. M. Rabinovich, V. A. Svobodin, A. A. Stepanov, V. I. Frolov, I. F. Khitskov, E. I. Tsaregorodtsev, A. V. Chayanov, A. A. Shut'kov, and other Russian researchers.

The issues of efficient management in poultry sector were researched in dissertations by G. A. Volkova, I. N. Lyakisheva, Yu. I. Segidov, V. I. Turevich, in monographs by V. I. Nechayev, S. D. Fetisov.

The analysis of these works have shown that the existing approaches to estimation and grounding of the ways to increase the agricultural production efficiency do not comprise the results of profound analysis of economic reserves, innovative technologies and the necessity to improve the human capital management. That negatively influences the economic development of poultry sector of a region and the national economy as a whole (Wang, Wang, \& Sun, 2013).

\section{Methodology}

In 2011 Tatarstan Republic housed 7 large poultry farms: "Ptitsezavod Bugulma" Ltd, "PTF Kazanskaya" Public Corporation, "PK Laishevskiy" Ltd, "SKhP Yubileynoye" Public Corporation, "PF Chistopolskaya" Ltd, "Chelny Broyler" Ltd, "PF Leninogorskaya" Ltd, "AF Ak Bars Pestretsy" Public Corporation. Statistical 
materials and financial reports of these enterprises were studied by the authors and allowed to reveal and estimate the role of production costs in increasing the efficiency of production-financial functioning of economic subjects. Using the economical-statistical, abstract-logical and monographic methods, the authors have graphically displayed the dynamics of costs structure in poultry sector, and the dependencies of the gross production costs per one bird place on egg production per one bird place (Nelson et al., 2010; Talanova \& Zaharov, 2010).

It is well known that the costs structure in poultry sector consists of remuneration of labour with social payments, costs for birds' feed, costs for fixed assets' maintenance, and others. To compare the costs dynamics, the relative indicators should be cast to each 100 sq.m. of a farm, i.e. the conditions should be typified in order to analyze the structure, trends and development prospects of the farms' production-financial functioning (Zaharov, 1994).

The dynamics of absolute sum increase and unit weight of reserves and costs can prove the inefficient utilization of production potential, the trend to protect the monetary assets against inflation, and unreasonable financial and economic strategy (Lin \& Martin, 2010).

\section{Data}

Analysis in poultry sector reveals the influence of the poultry farm structure on its financial-economic efficiency. The selective research allowed to make graphs and diagrams of "PTF Kazanskaya" Public Corporation and "SKhP Yubileynoye" Public Corporation.

During the research period, the overall costs per 100 sq.m. at "Ptitsezavod Bugulma" Ltd increased (the total area is 60 thousand sq.m.), though 2007 was an exception. The same trends was observed for feed expenses per 100 sq.m., while the expenses for remuneration of labour with social payments, as well as the costs for fixed assets' maintenance, remained stable and their management was fixed. The increase of feed costs can be explained by the increase of gross production cost per 100 sq.m., while the personnel management, i.e. the material incentives, is rather low. This conclusion is proved by the analysis of capital assets management, which shows that capital investment decreased.

Figure 1 shows the dynamics of costs at "PTF Kazanskaya" Public Corporation.

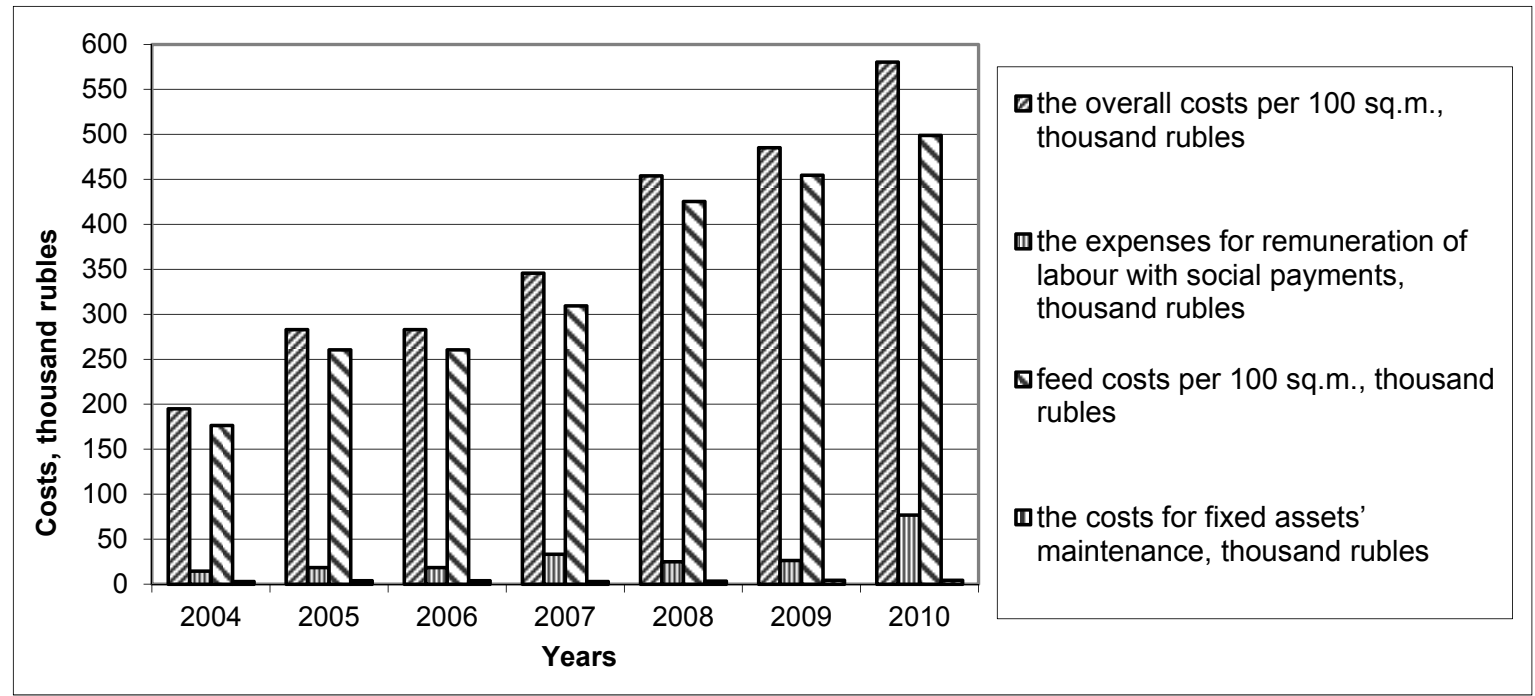

Figure 1. The dynamics of costs at "PTF Kazanskaya" Public Corporation

In 2004-2010, "PTF Kazanskaya" Public Corporation of Zelenodolsk Municipal district of Tatarstan Republic also showed the growth of costs per 100 sq.m., accompanied by the increase of feed costs (the total area is 93600 sq.m.). The share of costs for fixed assets' maintenance was too low compare with other costs. The fund for remuneration of labour with social payments was about 77 thousand rubles per 100 sq.m. in 2010.

"PK Laishevskiy" Ltd (the total area is 17280 sq.m.) did not show the increase of total costs per 100 sq.m. in 2004-2010. This indicator was the largest in 2008 - 1190,68 thousand rubles. The opposite trend was observed for the fixed assets' maintenance costs, which implies the high deterioration level, the low capital assets renovation level, requiring reconstruction and moderization of the farms' production-financial functioning. 
Figure 2 shows the dynamics of costs at "SKhP Yubileynoye" Public Corporation.

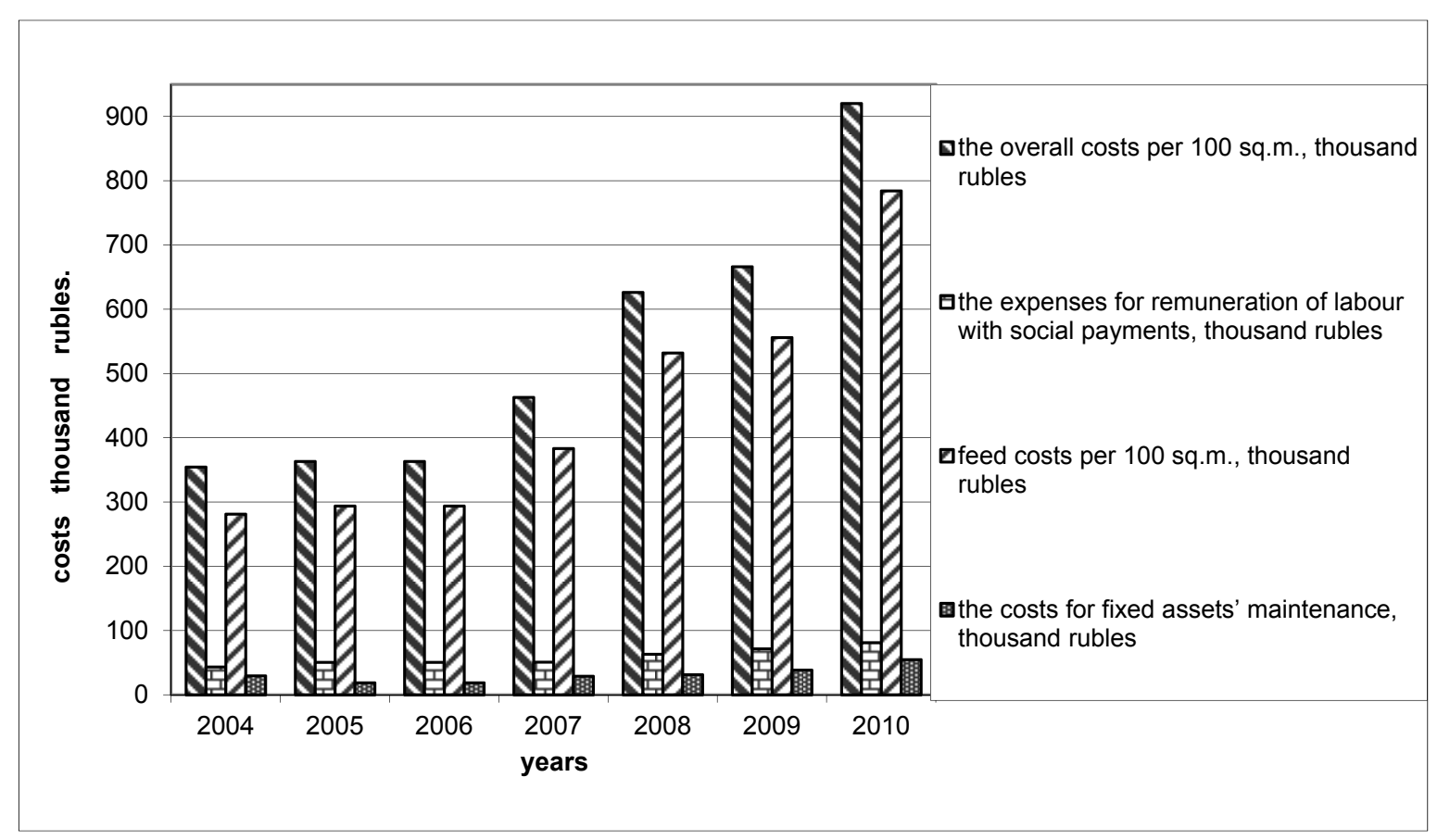

Figure 2. The dynamics of costs at "SKhP Yubileynoye" Public Corporation

Compared to "PK Laishevskiy" Ltd, "SKhP Yubileynoye" Public Corporation showed the positive dynamics of production-financial functioning costs. During the research period all costs grew, including the fund for remuneration of labour with social payments. The total area of the farm being 105696 sq.m., the managers achieved the reduction of total costs, and it was the largest in 2009 - 666,3 thousand rubles.

The costs dynamics of "PF Chistopolskaya" Ltd in 2004-2010 was ambiguous. The total are of the farm is 68 thousand sq.m. Since 2009 the total production-financial functioning costs decreased and in 2010 they amounted to 186 thousand rubles per 100 sq.m. In the same year the fixed assets' maintenance costs significantly decreased, though the fund for remuneration of labour with social payments was $92 \%$ compared to 2009 .

The total area of "Chelny Broyler" Ltd of Tukai municipal district of Tatarstan Republic is 247478 sq.m. The total costs per 100 sq.m. are growing, is due to the increase of feed costs, costs for remuneration of labour with social payments, and the fixed assets' maintenance costs. This trend may prove the increased demand and gross production, as well as egg production. We have also proved that the increase of variable costs is a characteristics of the increased intensity of production-financial functioning in poultry sector, by the example of "Chelny Broyler" Ltd. The growth rate of the fixed assets' maintenance costs exceed the growth rate of costs for remuneration of labour with social payments, which is an evidence of significant investment into the company's capital assets.

"PF Leninogorskaya" Ltd showed ambiguous trend of total costs per 100 sq.m. The largest costs took place in 2008, the least - in 2004. The costs structure was also contradictory. Unlike at "Chelny Broyler" Ltd, the costs for remuneration of labour with social payments exceeded the fixed assets' maintenance costs in 2006-2007 and in 2009-2010. That implies the growth of investment into human capital, the increase of material incentives depending on the gross income, which is a characteristic of effective multi-level management.

"AF Ak Bars Pestretsy" Public Corporation, situated in Pestrechinskiy municipal district of Tatarstan Republic has the total area of 76982 sq.m. Its characteristic is growth of cost per 100 sq.m., with the exception of 2009. This can be explained by the post-crisis condition in the regional and national economy. During the research period the fixed assets' maintenance costs per 100 sq.m. exceeded the costs for remuneration of labour with social payments. We have found that embodied labour prevails in "AF Ak Bars Pestretsy" Public Corporation, while investments into human capital decrease with time, which is a characteristic of inefficient management (LUKIĆ, 2013). 


\section{Empiric Results}

Figures 3 and 4 show the dependences of gross production cost per one bird place on the egg production per one bird place.

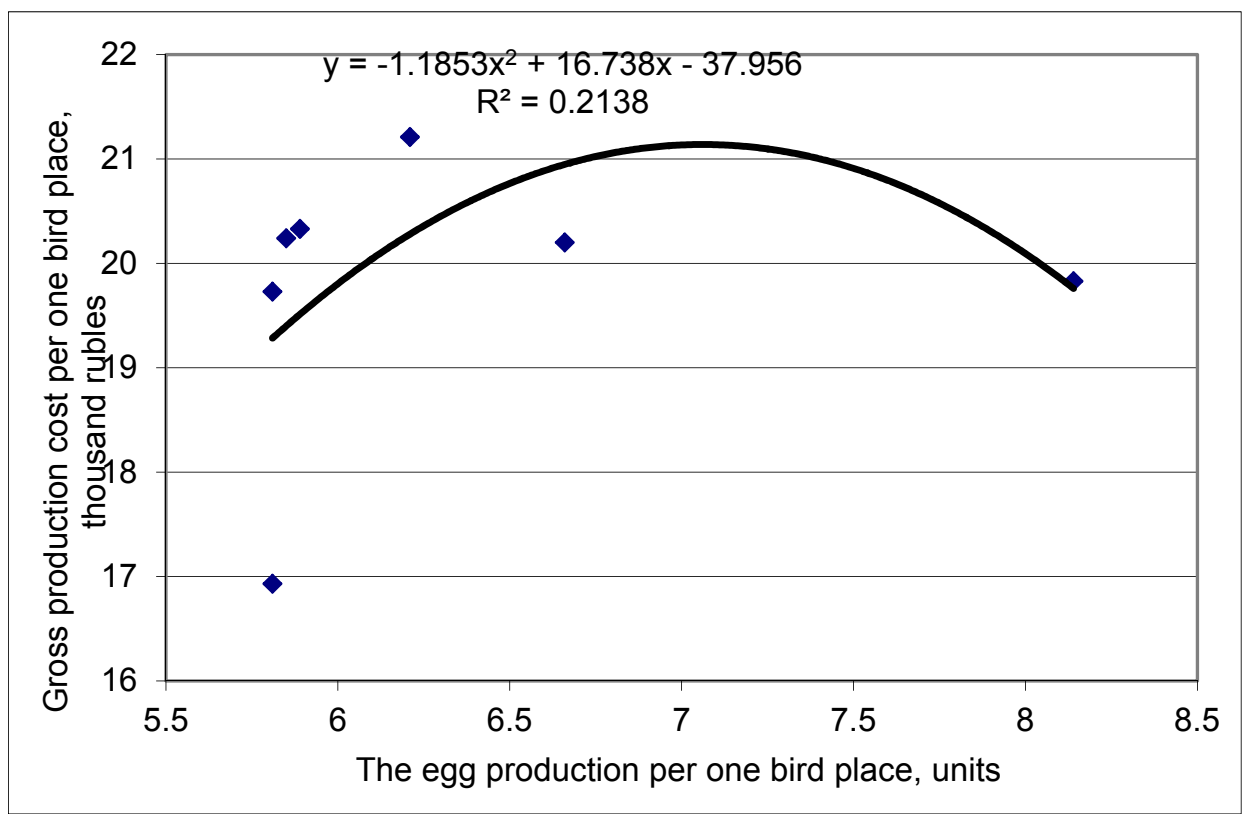

Figure 3. The dependences of gross production cost per one bird place on the egg production per one bird place "SKhP Yubileynoye"

Figure 3 shows that at "SKhP Yubileynoye" the gross production cost increases when the egg production per one bird place increases, but it decreases at egg production equal to 6,66 and 8,14 units. This dependency is described by a non-linear model of the second order with determination coefficient $R^{2}=0,214$. The initial value shows the weak correlation between the gross production cost increases and the egg production per one bird place.

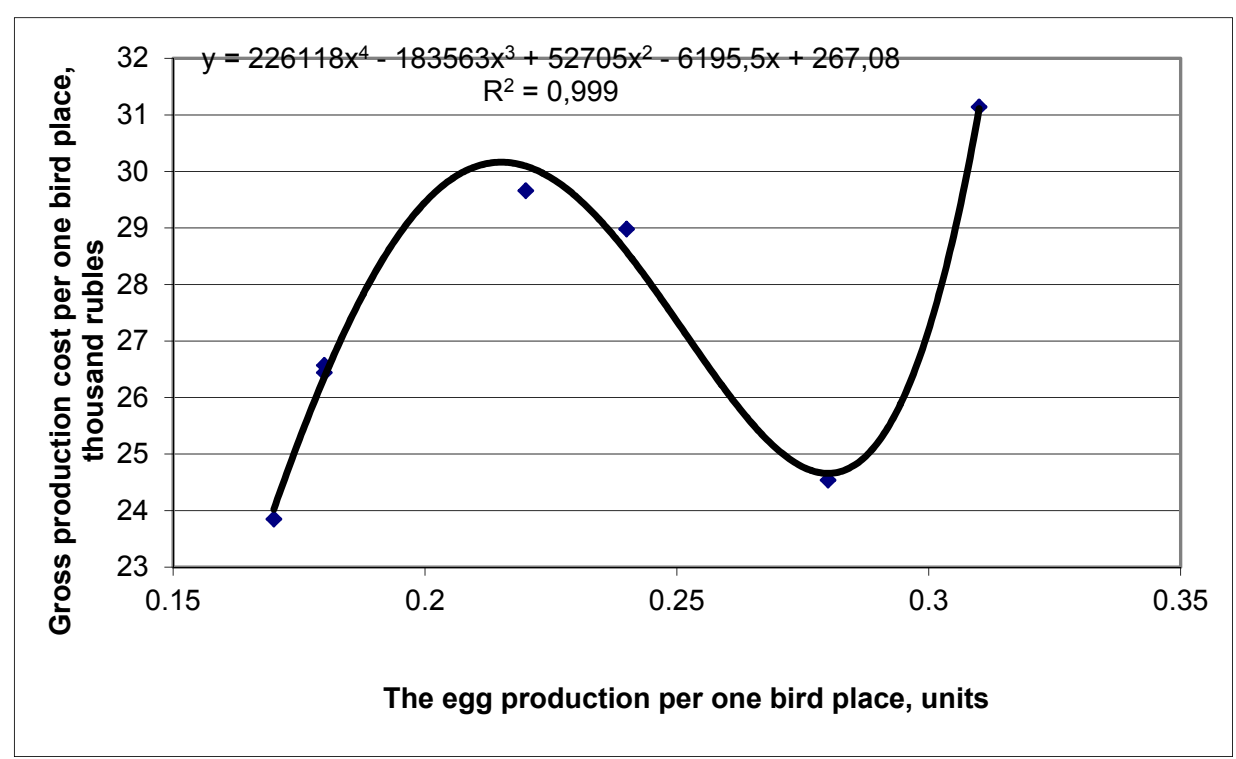

Figure 4. The dependences of gross production cost per one bird place on the egg production per one bird place "PK Laishevskiy" Ltd

Figure 4 shows that at "PK Laishevskiy" Ltd the gross production cost increases when the egg production per one bird place increases. This dependency is described by a non-linear model with determination coefficient $\mathrm{R}^{2}$ $=0,999$. 


\section{Conclusion}

The efficient management of production-financial functioning costs and structure will allow to achieve the increased efficiency of production-financial functioning of poultry farms, by increasing the gross production and egg production per 100 sq.m. These measures should be implemented with the account of internal and objective external factors, including innovative management, budget financing, special programs financing, and various forms of state-private partnership, which would increase the investment attraction of poultry sector.

\section{References}

Agapova, T. N., \& Kostyleva, L.V. (2000). Sravnitel'nyy analiz lichnykh podsobnykh khozyaystv gorodskogo i sel'skogo naseleniya. Voprosy statistiki, $8,45$.

Barrett, K. B. (2010). Izmereniye prodovol'stvennoy bezopasnosti. Nauka, 327.5967, 825-828.

Dobrynin, V. (2001). Tri glavnykh napravleniy vykhoda APK iz katastrofy. APK: ekonomika i upravleniye, 5, 50.

Dzh, D. F. (2012). Agrobiznes menedzhment. Routledge.

Gaynutdinova, F. S., Rabinovich, L. M., \& Timiryasov, V. G. (2000). Khozraschet na predpriyatiyakh agropromyshlennogo kompleksa. - Kazan': Izdatel'stvo "Taglimat" Instituta ekonomiki, upravleniya i prava.

Gibadullina, F. S., \& Zinnurov, I. A. (2006). Kak povysit' kachestvo ob"yemistykh kormov. Niva Tatarstana, 3-4, 34.

Lin, J. Y., \& Martin, W. (2010). The financial crisis and its impacts on global agriculture. Agricultural Economics, 41(1), 133-144.

LUKIĆ, R. (2013). Sustainable Cost Management in Retail. Review of International Comparative Management, 14(2), 268-280.

Marks, K., \& Engels, F. (n. d.). Kapital. Soch.-2 izd. T. 26. Ch. 2.703 s.

Nelson, G. C. et al. (2010). Food security, farming, and climate change to 2050: Scenarios, results, policy options. Intl Food Policy Res Inst.

Statisticheskiy sbornik. (2006). Selskoe hozyaystvo Respubliki Tatarstan: Kazan.

Talanova, A. N., \& Zaharov, V. P. (2010). Ryinok ekologicheski chistoy selskohozyaystvennoy produktsii: problemyi, perspektivyi, resheniya. Ekonomika selskohozyaystvennyih i pererabatyivayuschih predpriyatiy, $12,53-56$.

Tscharntke, T. et al. (2012). Global food security, biodiversity conservation and the future of agricultural intensification. Biological conservation, 151(1), 53-59.

Tunin, S. A. (2010). Klassifikatsiya zatrat v sisteme upravlencheskogo ucheta selskohozyaystvennyih organizatsiy. Dostizheniya nauki i tehniki APK, 9, 14-16.

Wang, L., Wang, Y., \& Sun, W. (2013). Study on the Relationship Between Human Capital Management and Agricultural Enterprise Performance-Based on Different Marketing Strategy. Proceedings of 20th International Conference on Industrial Engineering and Engineering Management (pp. 827-835). Springer Berlin Heidelberg.

Zaharov, V. P. (1994). Effektivnost selskohozyaystvennogo proizvodstva: faktoryi, rezervyi i puti povyisheniya. Kazan: Kazanskiy selskohozyaystvennyiy institute.

Zigangirova, A. M., \& Safiullina, A. M. (2011). K voprosu o metodah ekonomicheskoy effektivnosti selskohozyaystvennogo proizvodstva. Aktualnyie problemyi ekonomiki i prava.

\section{Copyrights}

Copyright for this article is retained by the author(s), with first publication rights granted to the journal.

This is an open-access article distributed under the terms and conditions of the Creative Commons Attribution license (http://creativecommons.org/licenses/by/3.0/ 